\title{
PENGARUH KESEMPATAN PROMOSI, PELATIHAN DAN LINGKUNGAN KERJA TERHADAP KEPUASAN KERJA KARYAWAN PADA PT. RUBBER HOCK LIE RANTAUPRAPAT
}

\author{
Siti Lam'ah Nasution \\ Dosen Tetap Sekolah Tinggi Ilmu Ekonomi (STIE) Labuhanbatu
}

\begin{abstract}
Abstrak
Penelitian ini bertujuan untuk mengetahui pengaruh Kesempatan Promosi, Pelatihan, dan Lingkungan Kerja terhadap Kepuasan Kerja Karyawan pada PT. Rubber Hock Lie Rantauprapat. Populasi dalam penelitian ini adalah seluruh karyawan pelaksana PT. Rubber Hock Lie Rantauprapat. Teknik penentuan jumlah sampel menggunakan rumus Slovin. Teknik pengambilan sampel menggunakan metode proporsionate random sampling. Metode analisis yang digunakan adalah metode analisis deskriptif kuantitatif. Data yang digunakan adalah data primer dan data sekunder yang diperoleh melalui studi dokumentasi dan kuesioner yang pengukurannya menggunakan skala likert dan diolah secara statistik dengan program SPSS 20.00 for windows.

Hasil dari penelitian ini menunjukkan bahwa variabel kesempatan promosi (X1), pelatihan (X2) dan lingkungan kerja (X3) secara bersama-sama berpengaruh positif dan signifikan terhadap kepuasan kerja karyawan pada PT. Rubber Hock Lie Rantauprapat yang ditunjukkan dengan nilai signifikansi 0,000 < 0,05. Secara parsial dapat dilihat bahwa variabel kesempatan promosi (X1) dan lingkungan kerja (X3) berpengaruh positif dan signifikan terhadap kepuasan kerja karyawan pada PT. Rubber Hock Lie Rantauprapat, sedangkan variabel pelatihan (X2) memiliki pengaruh yang tidak signifikan terhadap kepuasan kerja karyawan pada PT. Rubber Hock Lie Rantauprapat. Nilai Adjusted $R$ Square = 0,614, yang berarti 61,4\% variabel terikat dijelaskan oleh variabel bebas sedangkan sisanya 38,6\% dijelaskan oleh variabel lain yang diluar penelitian ini.
\end{abstract}

\section{A. Pendahuluan 1. Latar Belakang Masalah}

PT. Rubber Hock Lie merupakan perusahaan yang bergerak dalam bidang indutri pengolahan karet. Perusahaan ini telah beroperasi lebih dari 25 tahun dengan produk yang dihasilkan adalah Latex kering.Fenomena yang peneliti temukan pada pra survey yang dapat menyebabkan penurunan tingkat kepuasan kerja karyawan adalah bahwa promosi jabatan sulit didapatkan pada kalangan karyawan pelaksana. Penilaian pimpinan perusahaan yang subjektif sangat berperan dalam promosi jabatan ataupun meningkatkan jenjang karir, seperti karyawan pelaksana yang ingin naik jabatan menjadi karyawan pimpinan. Maka karyawan tersebut harus mengikuti seleksi untuk menjadi karyawan pimpinan. Walaupun kinerja karyawan pelaksana tergolong memuaskan, karyawan hanya dapat mengikuti seleksi promosi jabatan jika pimpinan berkenan memberikan kesempatan. Promosi jabatan dilakukan perusahaan sekali dalam 1 (satu) tahun atau dilakukan secara berkala sesuai kebutuhan dengan proses diusulkan, direkomendasikan dan keputusan yang keseluruhan membutuhkan waktu selama 30 (tiga puluh) hari. Kemudian fenomena lainnya yang peneliti temukan adalah mengenai program pelatihan 
yang diberikan perusahaan adalah tidak semua jenis pelatihan dapat diikuti oleh semua golongan karyawan. Ada beberapa pelatihan yang hanya bisa diikuti oleh karyawan pimpinan, tidak untuk karyawan pelaksana.Selain itu, peneliti menemukan fenomena lainnya mangenai hubungan antarkaryawan dengan atasan yaitu adanya batasan hubungan karyawan dengan pimpinan karyawan, tetapi batasan yang mengarah kepada musyawarah (demokrasi). Interaksi sosial antarkaryawan dengan atasan akan mempengaruhi lingkungan kerja yang menjadi salah satu indikator kepuasan kerja karyawan. Hubungan karyawan dengan pimpinan dan hubungan antar sesama karyawan yang baik akan mempengaruhi tingkat kepuasan kerja karyawan. Selain itu, pemberian gaji, tunjangan, fasilitas, dan bonus harus adil dan layak. PT. Rubber Hock Lie memberikan gaji, tunjangan, fasilitas, dan bonus sama rata secara adil dan layak kepada seluruh karyawan sesuai dengan golongannya.

Pemberian kesempatan promosi dan program pelatihan yang sulit diperoleh oleh karyawan pelaksana dapat mempengaruhi tingkat kepuasan karyawan. Khususnya jika karyawan merasa prestasi kerjanya tidak dinilai. Selain itu, hubungan antara karyawan dengan sesama karyawan dan hubungan karyawan dengan atasan yang kurang terbuka akan menyebabkan terhambatnya komunikasi di dalam perusahaan dan hal itu mempengaruhi suasana lingkungan kerja karyawan. Fenomena-fenomena yang peneliti temukan dapat menjadi masalah besar pada perusahaan jika tidak di perhatikan.Berdasarkan uraian tersebut, peneliti tertarik untuk mengadakan penelitian yang berjudul, "Peranan Kesempatan Promosi, Pelatihan, dan Lingkungan Kerja Terhadap Kepuasan Kerja Karyawan pada PT. Rubber Hock Lie Rantauprapat."

\section{Batasan dan Rumusan Masalah}

Ada banyak faktor atau variabel yang dapat mempengaruhi kinerja karyawan. Penelitian ini memfokuskan pembahasan pada Peranan Kesempatan Promosi, Pelatihan, dan Lingkungan Kerja Terhadap Kepuasan Kerja Karyawan pada PT. Rubber Hock Lie Rantauprapat.

Berdasarkan latar belakang yang telah diuraiakan sebelumnya, peneliti mengambil rumusan masalah penelitian sebagai berikut :

1. Apakah kesempatan promosi secara parsial berpengaruh terhadap kepuasan kerja karyawan pada PT. Rubber Hock Lie Rantauprapat;

2. Apakah pelatihan secara parsial berpengaruh terhadap kepuasan kerja karyawan pada PT. Rubber Hock Lie Rantauprapat;

3. Apakah lingkungan kerja secara parsial berpengaruh terhadap kepuasan kerja karyawan pada PT. Rubber Hock Lie Rantauprapat;

4. Apakah kesempatan promosi, pelatihan, dan lingkungan kerja secara simultan berpengaruh terhadap kepuasan kerja karyawan pada PT. Rubber Hock Lie Rantauprapat.

\section{Tujuan Penelitian}

Adapun Tujuan dari penelitian ini adalah :

1. Untuk mengetahui pengaruh kesempatan promosi terhadap kepuasan kerja karyawan pada PT. Rubber Hock Lie Rantauprapat;

2. Untuk mengetahui pengaruh pelatihan terhadap kepuasan kerja karyawan pada PT. Rubber Hock Lie Rantauprapat;

3. Untuk mengatahui pengaruh lingkungan kerja terhadap kepuasan kerja karyawan pada PT. Rubber Hock Lie Rantauprapat; 
4. Untuk mengatahui pengaruh kesempatan promosi, pelatihan, dan lingkungan kerja terhadap kepuasan kerja karyawan pada PT. Rubber Hock Lie Rantauprapat.

\section{B. Tinjauan Pustaka 1. Uraian Teoritis}

Menurut Hasibuan (2011:108) promosi adalah perpindahan yang memperbesar authority dan responsibility karyawan ke jabatan yang lebih tinggi di dalam suatu organisasi sehingga kewajiban, hak, status, dan penghasilan semakin besar. Berarti ada kepercayaan dan pengakuan mengenai kemampuan serta kecakapan karyawan untuk menduduki jabatan yang lebih tinggi. Dengan demikian, promosi akan memberikan status sosial, wewenang (authority), tanggung jawab (responsibility), serta penghasilan (outcomes) yang semakin besar bagi karyawan. Maka karyawan tersebut akan merasa puas akan pekerjaannya, dan merasa diakui oleh perusahaan.

Pelatihan adalah proses untuk mempertahankan atau memperbaiki keterampilan karyawan untuk menghasilkan pekerjaan yang efektif (Bangun, 2012:201). Pelatihan harus diberikan kepada setiap karyawan dalam perusahaan. Para manajer perusahaan harus menyadari betapa pentingnya pelatihan untuk meningkatkan kepuasan kerja.

Lingkungan kerja merupakan bagian komponen yang sangat penting bagi karyawan dalam menjalankan pekerjaannya selama di kantor. Jadi kelengkapan alat dan ketenangan serta kenyamanan ruangan bekerja sangat mempengaruhi perasaan senang atau tidak senang seorang karyawan di perusahaan tersebut.

Hasibuan (2011:202) mengungkapkan kepuasan kerja adalah sikap emosional yang menyenangkan dan mencintai pekerjaannya. Kepuasan kerja karyawan dapat dipengaruhi oleh faktor sosial, faktor fisik, dan faktor finansial. Adanya pemberian kesempatan promosi, pelatihan yang adil kepada seluruh karyawan, dan pemeliharaan perusahaan terhadap lingkungan kerja karyawan akan berperan terhadap tingkat kepuasan kerja karyawan.

\section{Kerangka Konseptual}

Adapun kerangka konseptual penelitian ini dapat digambarkan sebagai berikut: 


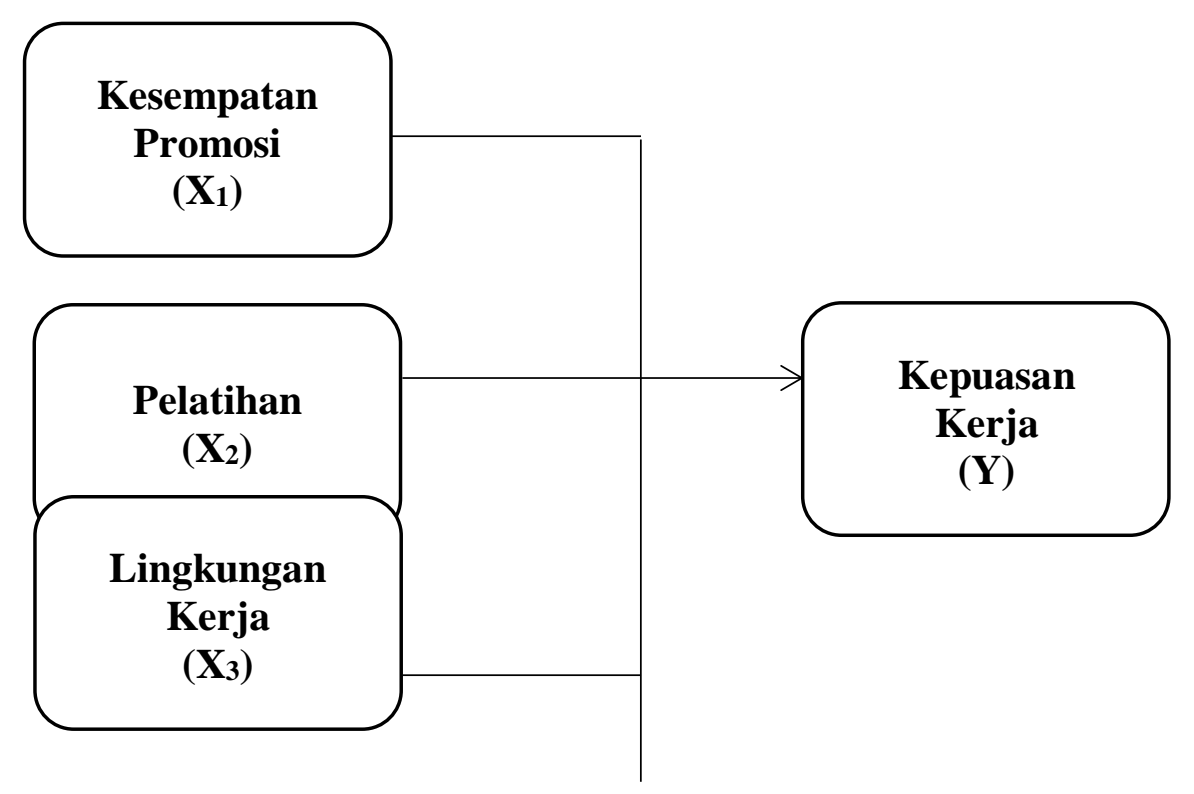

\section{Hipotesis}

Hipotesis merupakan jawaban sementara terhadap rumusan masalah penelitian (Sugiyono, 2012:93). Berdasarkan perumusan masalah dan kerangka konseptual, maka hipotesis dalam penelitian ini adalah:

1. Kesempatan promosi berpengaruh positif dan signifikan terhadap kepuasan kerja karyawan pada PT. Rubber Hock Lie Rantauprapat;

2. Pelatihan berpengaruh positif dan signifikan terhadap kepuasan kerja karyawan pada PT. Rubber Hock Lie Rantauprapat;

3. Lingkungan kerja berpengaruh positif dan signifikan terhadap kepuasan kerja karyawan pada PT. Rubber Hock Lie Rantauprapat;

4. Kesempatan promosi, Pelatihan, dan Lingkungan kerja berpengaruh positif dan signifikan terhadap kepuasan kerja karyawan pada PT. Rubber Hock Lie Rantauprapat.

\section{Metode Penelitian 1. Populasi dan Sampel}

Jumlah populasi dalam penelitian ini adalah 245 karyawan. Sampel yang diambil dalam penelitian ini berjumlah 71 orang karyawan pelaksana pada PT. Rubber Hock Lie.Teknik penarikan sampel yang digunakan dalam penelitian ini adalah Proportional Random Sampling yaitu teknik pengambilan sampel anggota populasi yang dilakukan dengan proporsional.

\section{Metode Analisis Data a. Metode Analisis Deskriptif}

Metode penelitian deskriptif adalah penelitian yang dilakukan untuk mengetahui nilai-nilai variabel, baik satu variabel ataupun lebih tanpa membuat perbandingan atau menghubungkan dengan variabel lain dan untuk mengetahui nilai dari fenomena yang terjadi pada suatu organisasi/perusahaan. Penganalisaan data dilakukan dengan cara menyusun data, mengelompokkannya, kemudian menginterprestasikannya sehingga diperoleh gambaran yang sebenarnya mengenai kondisi perusahaan. b. Uji Asumsi Klasik

1) Uji Normalitas 
Tujuan uji normalitas adalah untuk mengetahui apakah distribusi sebuah data mengikuti atau mendekati distribusi normal(Situmorang dan Lufti, 2012:100). Uji normalitas pada penelitian ini dilakukan dengan menggunakan pendekatan histogram, grafik dan Kolmogorv-Smirnov dengan menggunakan tingkat signifikan $5 \%$.

2) Uji Multikolinearitas

Uji multikolinearitas bertujuan untuk mengetahui ada atau tidaknya hubungan linear yang sempurna atau eksak diantara variabel-variabel bebas dalam model regresi (Situmorang dan Lufti, 2012:133).

Adanya multikolinearitas dapat dilihat dari Tolerance value atau nilai Variance Inflation Factor (VIF). Batas Tolerance value adalah 0,1 dan batas VIF adalah 5 . Apabila Tolerance value $<0,1$ atau VIF $>5$ maka terjadi multikolinieritas. Tetapi jika Tolerance value $>0,1$ atau VIF $<5$ maka tidak terjadi multikolinearitas.

3) Uji Heteroskedastisitas

Uji heteroskedastisitas bertujuan untuk menguji apakah sebuah grup mempunyai varians yang sama di antara anggota grup tersebut. Jika varians sama, dan ini yang seharusnya terjadi maka dikatakan ada homoskedastisitas. Sedangkan jika varians tidak sama dikatakan terjadi heteroskedastisitas (Situmorang dan Lufti, 2012:108).

Uji heteroskedastisitas dalam penelitian ini dilakukan dengan menggunakan pendekatan grafik dengan menggunakan tingkat signifikan 5\%. Jika probabilitasnya signifikannya di atas tingkat kepercayaan 5\% dapat disimpulkan model regresi tidak mengarah adanya heteroskedastisitas (Situmorang dan Lufti, 2011: 119).

\section{c. Analisis Regresi Linear Berganda}

Analisis regresi digunakan untuk mengetahui bagaimana variabel dependent dapat diprediksi melalui variabel independent secara individual.Analisis regresi linear berganda ditujukan untuk menentukan hubungan linier antara beberapa variabel bebas yang disebut $\mathrm{X}_{1}, \mathrm{X}_{2}, \mathrm{X}_{3}$ dengan variabel terikat yang disebut $\mathrm{Y}$. (Situmorang dan Lufti, 2012:151).

Untuk memperoleh hasil analisis data, maka peneliti menggunakan bantuan program SPSS 22.0.0 for Windows. Model Persamaannya dapat digambarkan sebagai berikut:

$$
\begin{aligned}
& \mathbf{Y = a}+\mathbf{b}_{1} \mathbf{X}_{\mathbf{1}}+\mathbf{b}_{2} \mathbf{X}_{\mathbf{2}}+\mathbf{b}_{3} \mathbf{X}_{\mathbf{3}}+\boldsymbol{e} \\
& \text { Dimana : } \\
& \mathrm{Y} \quad=\text { Kepuasan kerja } \\
& \mathrm{a} \quad \text { Konstanta } \\
& \mathrm{b}_{1}, \mathrm{~b}_{2}, \mathrm{~b}_{3}=\text { Koefisien regresi } \\
& \mathrm{X}_{1} \quad=\text { Kesempatan promosi } \\
& \mathrm{X}_{2} \quad=\text { Pelatihan } \\
& \mathrm{X}_{3} \quad=\text { Lingkungan kerja } \\
& e \quad=\text { Standar error }
\end{aligned}
$$

\section{d. Uji Hipotesis}

1) Uji Signifikansi Parsial (Uji t)

Uji $\mathrm{t}$ bertujuan untuk mengetahui besarnya pengaruh masing-masing variabel independent secara individu (parsial) terhadap variabel dependent. Kriteria pengambilan keputusannya adalah sebagai berikut : 
1)Ho diterima atau Ha ditolak jika $\mathrm{t}_{\text {hitung }}<\mathrm{t}_{\text {tabel }}$ pada $\alpha=5 \%$

2) Ho ditolak atau Ha diterima jika $t_{\text {hitung }}>t_{\text {tabel }}$ pada $\alpha=5 \%$

2) Uji Signifikansi Simultan (Uji F)

Uji $\mathrm{F}$ bertujuan untuk mengetahui pengaruh secara serentak atau bersama-sama variabel independent (kesempatan promosi, pelatihan, dan lingkungan kerja) terhadap variabel dependent (kepuasan kerja karyawan).

Kriteria pengujiannya adalah sebagai berikut:

1) Ho diterima atau Ha ditolak jika $F_{\text {hitung }}<F_{\text {tabel }}$ pada $=5 \%$

2) Ho ditolak dan Ha diterima jika $F_{\text {hitung }}>F_{\text {tabel }}$ pada $=5 \%$

Jika tingkat signifikansi di bawah 0,05 maka Ho ditolak dan Ha diterima. Jikapada perhitungan $F_{\text {hitung }}>F_{\text {tabel }}$ dan tingkat signifikansinya $(0,000)<0,05$ maka menunjukkan bahwa pengaruh variabel independent secara serempak adalah signifikan terhadap kepuasan kerja karyawan.

3) Koefisien Determinasi $\left(R^{2}\right)$

Koefisien determinasi bertujuan untuk mengukur seberapa jauh kemampuan model dalam menerangkan variasi variabel independent atau predictor-nya. Semakin besar nilai koefisien determinasi, maka semakin baik kemampuan variabel independent menerangkan varibel dependent.Range nilai $0 \leq R^{2} \leq 1$. Semakin mendekati nol berarti model tidak baik atau variasi model dalam menjelaskan sangat terbatas, sebaliknya semakin mendekati satu maka model semakin baik. (Situmorang dan Lufti, 2012:154).

\section{Hasil dan Pembahasan 1. Hasil Penelitian a. Uji Asumsi Klasik}

1) Uji Normalitas

Uji normalitas bertujuan untuk mengetahui apakah distribusi sebuah data mengikuti atau mendekati distribusi normal, yakni distribusi data dengan bentuk lonceng. Data yang baik adalah data yang mempunyai pola distribusi normal, yakni data tidak menceng ke kiri atau menceng ke kanan.

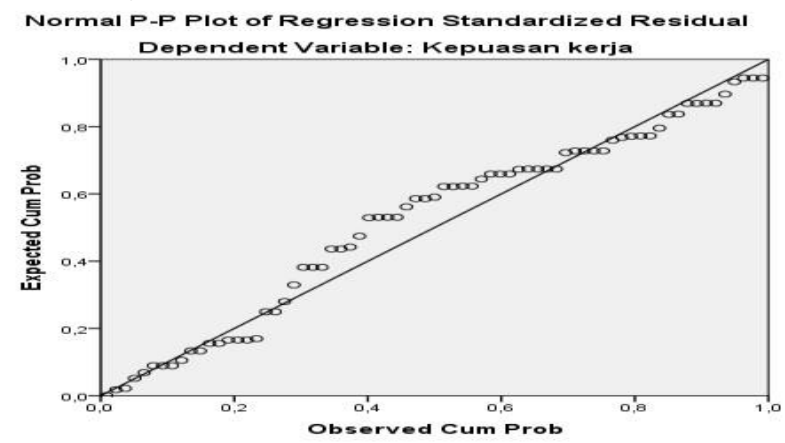

PadagrafikNormal P-P Plotterlihattitik yang mengikuti data di sepanjanggarisdiagonal.Hal iniberarti data berdistribusi normal.

Untuk Uji Kolmogorov-Smirnovdilakukan melalui Non Parametric Test, hasilnya seperti pada Tabel berikut :

TabelHasilUji Kolmogorov-Smirnov

One-Sample Kolmogorov-Smirnov Test

\begin{tabular}{|l|l|}
\hline & $\begin{array}{c}\text { Unstandardized } \\
\text { Residual }\end{array}$ \\
\hline $\mathrm{N}$ & 71 \\
\hline
\end{tabular}




\begin{tabular}{|ll|r|} 
Normal Parameters ${ }^{\mathrm{a}, \mathrm{b}}$ & Mean & $0 \mathrm{E}-7$ \\
& Std. Deviation &, 68803289 \\
& Absolute &, 135 \\
Most Extreme Differences & Positive &, 075 \\
& Negative &,- 135 \\
& & 1,142 \\
Kolmogorov-Smirnov Z & \\
Asymp. Sig. (2-tailed) & \\
\hline
\end{tabular}

a. Test distribution is Normal.

b. Calculated from data.

PadaTabel 4.8terlihatbahwanilaiAsymp. Sig. (2-tailed)adalah 0,758. Dengan demikian nilai Asymp. Sig. (2-tailed) 0,147 > 0,05 yang berartivariabel residual berdistribusi normal.

2) Uji Multikolinearitas

Suatu variabel menunjukkan gejala multikolinieritas bisa dilihat dari nilai Tolerance dan nilai Variance Inflation Factor (VIF). Nilai Tolerance > 0,1 dan VIF < 10, maka tidak terdapat multikolienaritas dalam model regresi.

\section{Tabel Hasil Uji Multikolinearitas}

\begin{tabular}{|c|c|c|}
\hline \multirow[t]{2}{*}{ Model } & \multicolumn{2}{|c|}{ Collinearity Statistics } \\
\hline & Tolerance & VIF \\
\hline (Constant) & & \\
\hline Kesempatan promosi & ,439 & 2,276 \\
\hline Pelatihan & ,528 & 1,895 \\
\hline Lingkungan kerja & ,461 & 2,171 \\
\hline
\end{tabular}

Hasil pengujian yang ditampilakn pada Tabel 4.9 menunjukkan bahwa semua variabel yang digunakan sebagai prediktor model regresi menunjukkan nilai Tolerance $>$ 0,1 dan nilai $V I F<10$. Hal ini berarti bahwa variabel-variabel bebas yang digunakan dalam penelitian tidak menunjukkan adanya gejala multikolinieritas dan dapat digunakan sebagai variabel yang saling independen.

3) Uji Heteroskedostisitas

Uji heteroskedostisitas bertujuan mengetahui apakah dalam model regresi terjadi ketidaksamaan varians dari satu residual pengamatan ke pengamatan lain. Jika varians dari residual satu pengamatan ke pengamatan yang lain tetap, maka disebut homoskedastisitas dan jika berbeda disebut heteroskedastisitas. Model regresi yang baik adalah yang homokedastisitas atau tidak terjadi heteroskedastisitas.

Uji heteroskedastisitas dilakukan dengan menganalisis penyebaran titik-titik yang terdapat pada Scatterplot yang dihasilkan program SPSS dengan dasar pengambilan keputusan yaitu jika ada pola tertentu, seperti titik-titik yang ada membentuk suatu pola tertentu yang teratur (bergelombang, melebar, kemudian menyempit) maka terjadi heteroskedastisitas, sedangkan jika tidak ada pola yang jelas serta titik-titik menyebar di atas dan di bawah angka 0 pada sumbu Y, maka tidak terjadi heteroskedastisitas. 


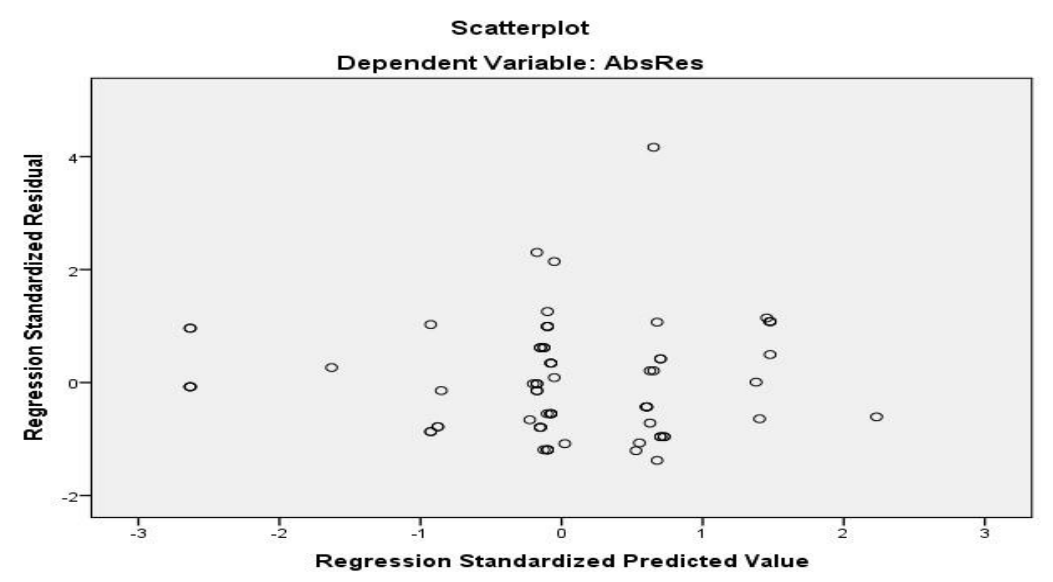

Berdasarkan gambar diatas terlihat bahwa titik-titik menyebar diatas dan dibawah 0 pada sumbu Y. Dengan demikian dapat disimpulkan bahwa tidak terjadi heteroskedostisitas dalam model regresi.

Uji heteroskedastisitas dapat juga dilakukan dengan menggunakan uji Glejser dengan cara meregresi nilai absolut residual terhadap variabel independen. Jika nilai Sig< 0,05 maka ada indikasi terjadi heteroskedastisitas, akan tetapi jika nilai Sig> 0,05 maka tidak terjadi heteroskedostisitas.

Tabel Hasil Uji Glejser

Coefficients $^{\mathrm{a}}$

\begin{tabular}{|c|c|c|c|c|c|c|}
\hline \multicolumn{2}{|c|}{ Model } & \multicolumn{2}{|c|}{ Unstandardized Coefficients } & \multirow{2}{*}{$\begin{array}{c}\text { Standardized } \\
\text { Coefficients } \\
\text { Beta }\end{array}$} & \multirow[t]{2}{*}{$\mathrm{t}$} & \multirow[t]{2}{*}{ Sig. } \\
\hline & & $B$ & Std. Error & & & \\
\hline \multirow{4}{*}{1} & (Constant) &,- 550 & ,706 & &,- 780 & ,438 \\
\hline & Kesempatanpromosi &,- 002 & ,058 &,- 007 &,- 037 & ,971 \\
\hline & Pelatihan & ,068 & ,054 & ,206 & 1,256 & ,213 \\
\hline & Lingkuniganikeija &, 007 &, 063 & ,018 & ,104 & 917 \\
\hline
\end{tabular}

a. Dependent Variable: AbsRes

Berdasarkan Tabel 4.10 diatas diketahui bahwa untuk variabel Kesempatan promosi $\left(\mathrm{X}_{1}\right)$ nilai Sig 0,971, untuk variabel Pelatihan $\left(\mathrm{X}_{2}\right)$ nilai Sig 0,213, dan untuk variabel lingkungan kerja $\left(\mathrm{X}_{3}\right)$ nilai Sig 0,917. Dengan demikian untuk ketiga variabel tersebut nilai Sig nya $>0,05$, sehingga kesimpulannya tidak terjadi heteroskedostisitas dalam model regresi.

\section{b. Analisis Regresi Linear Berganda}

Analisis regresi linear berganda ditujukan untuk mengetahui pengaruh atau hubungan variabel bebas $\left(\mathrm{X}_{1}, \mathrm{X}_{2}\right.$, dan $\left.\mathrm{X}_{3}\right)$ serta variabel terikat $(\mathrm{Y})$, maka untuk memperoleh hasil yang lebih akurat, peneliti menggunakan bantuan program software SPSS (Statistik Product and Service Solution) versi 20.0, maka dihasilkan output sebagai berikut :

\section{Tabel Koefisien Regresi}

Coefficients $^{\mathrm{a}}$

\begin{tabular}{|l|r|r|r|r|r|}
\hline Model & \multicolumn{2}{|c|}{$\begin{array}{c}\text { Unstandardized Coefficients } \\
\text { B }\end{array}$} & $\begin{array}{c}\text { Standardized } \\
\text { Coefficients } \\
\text { Beta }\end{array}$ & $\mathrm{t}$ & Sig. Error \\
\hline 2,711 & 1,214 & & 2,232 &, 029 \\
\hline
\end{tabular}




\begin{tabular}{|c|c|c|c|c|c|}
\hline (Constant) & ,263 &, 100 & ,296| & 2,637 & ,010 \\
\hline Kesempatanpromosi & ,099| & ,093 & |109| & 1,061 & 292 \\
\hline $\begin{array}{l}\text { Pelatihan } \\
\text { Lingkungankerja }\end{array}$ & ,471 & , 108 & ,477 & 4,359 & 000 \\
\hline
\end{tabular}

a. Dependent Variable: Kepuasankerja

Berdasarkan Tabel diatas, jika dilihat nilai B pada kolom Unstandardized Coefficients maka dapat diketahui nilai koefisien masing-masing variabel.

a) Konstanta (a) $=2,711$. Nilai ini mempunyai arti bahwa jika variabel kesempatan promosi, pelatihan, dan lingkungan kerja bernilai 0, maka kepuasan kerja (Y) sebesar 2,711.

b) Koefisien $X_{1}\left(b_{1}\right)=0,263$. Nilai ini mempunyai arti bahwa jika kesempatan promosi naik sebesar 1 satuan, maka kepuasan kerja akan naik sebesar 0,263.

c) Koefisien $X_{2}\left(b_{2}\right)=0,099$. Nilai ini mempunyai arti bahwa jika pelatihan naik sebesar 1 satuan, maka kepuasan kerja akan naik sebesar 0,099.

d) Koefisien $X_{3}\left(b_{3}\right)=0,471$. Nilai ini mempunyai arti bahwa jika lingkungan kerja naik sebesar 1 satuan, maka kepuasan kerja akan naik sebesar 0,471.

Dari nilai tersebut dapat dibentuk suatu model persamaan regresi sebagai berikut

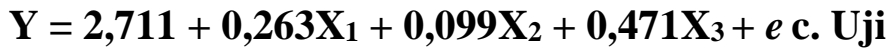

\section{Hipotesis}

1) Uji Parsial (Uji t)

Uji parsial (Uji t) digunakan untuk membuktikan pengaruh kesempatan promosi, pelatihan, dan lingkungan kerja terhadap kepuasan kerja (Y) secara parsial. Nilai thitung diperoleh dari hasil SPSS, sedangkan nilai tabel yang digunakan adalah nilai t pada $\alpha=$ 0,05 dengan derajat kebebasan $(\mathrm{df}=71)$ yaitu $1,66660=1,667$. Tabel Hasil Uji Parsial (Uji t)

\begin{tabular}{|c|c|c|c|c|c|c|}
\hline \multicolumn{7}{|c|}{ Coefficients $^{a}$} \\
\hline \multirow{2}{*}{\multicolumn{2}{|c|}{ Model }} & \multicolumn{2}{|c|}{ Unstandardized Coefficients } & \multirow{2}{*}{$\begin{array}{c}\text { Standardized } \\
\text { Coefficients } \\
\text { Beta }\end{array}$} & \multirow[t]{2}{*}{$\mathrm{t}$} & \multirow[t]{2}{*}{ Sig. } \\
\hline & & $B$ & Std. Error & & & \\
\hline \multirow{4}{*}{1} & (Constant) & 2,711 & 1,214 & & 2,232 & ,029 \\
\hline & Kesempatanpromosi & ,263 & 100 & , 296 & 2,637 & , 010 \\
\hline & Pelatihan & ,099 & ,093 & , 109 & 1,061 & ,292 \\
\hline & Lingkungankerja & ,471 & , 108 & ,477 & 4,359 & ,000 \\
\hline
\end{tabular}

a. Dependent Variable: Kepuasankerja

Berdasarkan Tabel, dapat dijelaskan sebagai berikut :

1) Untuk variabel kesempatan promosi $\left(X_{1}\right)$, diperoleh nilai thitung yaitu 2,637 dan dengan taraf signifikansi 0,010 . Jika dibandingkan dengan nilai $t_{\text {tabel, }}$ maka $t_{\text {hitung }}$ $(2,637)>t_{\text {tabel }}(1,667)$ dan taraf signifikasi $0,010<0,05$. Hal ini berarti bahwa secara parsial kesempatan promosi berpengaruh signifikan terhadap kepuasan kerja karyawan pada PT. Rubber Hock Lie Rantauprapat. Dengan demikian berarti hipotesis dapat diterima.

2) Untuk variabel pelatihan $\left(X_{2}\right)$, diperoleh nilai thitung yaitu 2,129 dan taraf signifikansi 0,036. Jika dibandingkan dengan nilai $t_{\text {tabel}}$, maka $t_{\text {hitung }}(1,061)<t_{\text {tabel }}$ $(1,667)$ dan taraf signifikansi 0,292 >0,05. Hal ini berarti bahwa secara parsial 
pelatihan berpengaruh tidak signifikan terhadap kepuasan kerja karyawan pada PT. Rubber Hock Lie Rantauprapat. Dengan demikian hipotesis ditolak.

3) Untuk variabel lingkungan kerja $\left(X_{3}\right)$, diperoleh nilai thitung yaitu 4,359 dan taraf signifikansi 0,00 . Jika dibandingkan dengan nilai $t_{\text {tabel, }}$, maka $t_{\text {hitung }}(4,359)>t_{\text {tabel }}$ $(1,667)$ dan taraf signifikansi $0,00<0,05$. Hal ini berarti bahwa secara parsial lingkungan kerja berpengaruh signifikan terhadap kepuasan kerja karyawan pada PT. Rubber Hock Lie Rantauprapat. Dengan demikian hipotesis dapat diterima.

2) Uji Simultan (Uji F)

Uji signifikasi simultan (uji F) digunakan untuk membuktikan pengaruh kesempatan promosi, pelatihan, dan lingkungan kerja secara bersama-sama (simultan) terhadap kepuasan kerja karyawan pada PT. Rubber Hock Lie Rantauprapat. Hasil uji simultan (uji F) di tampilkan pada Tabel berikut :

Tabel Hasil Uji Simultan (Uji F)

ANOVA $^{\mathrm{a}}$

\begin{tabular}{|c|c|c|c|c|c|}
\hline Model & Sum of Squares & df & Mean Square & $F$ & Sig. \\
\hline $\begin{array}{l}\text { Regression } \\
\text { Residual } \\
\text { Total }\end{array}$ & $\begin{array}{l}56,440 \\
33,137 \\
89,577\end{array}$ & $\begin{array}{r}3 \\
67 \\
70\end{array}$ & $\begin{array}{r}18,813 \\
, 495\end{array}$ & 38,039 &, $000^{b}$ \\
\hline
\end{tabular}

a. Dependent Variable: Kepuasankerja

b. Predictors: (Constant), Lingkungankerja, Pelatihan, Kesempatanpromosi

Berdasarkan Tabel diatas, diperoleh nilai $F_{\text {hitung }}$ sebesar 38,039 dan nilai Sig 0,000. Sedangkan nilai $\mathrm{F}_{\text {tabel }}$ yang digunakan adalah nilai distribusi $\mathrm{F}$ dengan derajat kebebasan $\mathrm{df}_{1}(3)$ dan $\mathrm{df}_{2}(67)$ pada $\alpha=0,05$. Selanjutnya nilai $F_{\text {hitung }}$ dibandingkan dengan nilai $F_{\text {tabel }}$ , maka diperoleh $F_{\text {hitung }}(112,048)>F_{\text {tabel }}(2,74)$ dan taraf signifikasi $0,00<0,05$. Hal ini menunjukkan bahwa kesempatan promosi, pelatihan, dan lingkungan kerja secara simultan (bersama-sama) berpengaruh signifikan terhadap kepuasan kerja karyawan pada PT. Rubber Hock Lie Rantauprapat. Dengan demikian hipotesis dapat diterima.

3) Koefisien Determinasi

Koefisien determinan mengukur seberapa jauh kemampuan model dalam menerangkan variasi variabel independen. Nilainya adalah $0-1$. Semakin mendekati nol berarti model regresi semakin tidak baik atau model dalam menjelaskan dengan sangat terbatas, dan sebaliknya semakin mendekati satu, maka model semakin baik.

Tabel Koefisien Determinasi Model Summaryb

\begin{tabular}{l|r|r|r|r|}
\hline Model & $\mathrm{R}$ & $\mathrm{R}$ Square & $\begin{array}{c}\text { Adjusted R } \\
\text { Square }\end{array}$ & $\begin{array}{c}\text { Std. Error of the } \\
\text { Estimate }\end{array}$ \\
\hline 1 &, $794^{\mathrm{a}}$ &, 630 &, 614 &, 703 \\
\hline
\end{tabular}
a. Predictors: (Constant), Lingkungankerja, Pelatihan,
Kesempatanpromosi


Besarnya koefesien determinasi $\left(R^{2}\right)$ dapat dilihat pada kolom Adjusted $R$ Square yaitu sebesar 0,614 . Nilai ini berarti bahwa kepuasan kerja karyawan mampu dipengaruhi oleh kesempatan promosi, pelatihan, dan lingkungan kerja sebesar $61,4 \%$. Sedangkan sisanya sebesar 38,6\% (100\% - 61,4\%) dipengaruhi variabel lain yang tidak diteliti dalam penelitian ini.

\section{Pembahasan}

\section{a. Pengaruh Kesempatan Promosi Terhadap Kepuasan Kerja Karyawan Pada PT. Rubber Hock Lie Rantauprapat}

Kepuasan kerja dipandang sebagai suatu reaksi emosional yang merupakan akibat dari dorongan, keinginan, tuntutan dan harapan-harapan karyawan terhadap pekerjaan yang dihubungkan dengan realitas yang dirasakan oleh karyawan (Sutrisno, 2013:74). Setelah melakukan uji t, kesempatan promosi berpengaruh secara positif dan signifikan terhadap kepuasan kerja karyawan, karena promosi merupakan salah satu harapan karyawan selama bekerja. Dengan mendapatkan kesempatan promosi berarti karyawan tersebut memperoleh penghargaan atas prestasinya, diakui kinerjanya, dan diberi tanggung jawab yang lebih besar. Hal ini sesuai dengan jawaban responden menyatakan bahwa mereka sangat puas dengan adanya penghargaan dari perusahaan atas keahlian dalam bentuk pemberian kesempatan promosi.

\section{b. Pengaruh Pelatihan Terhadap Kepuasan Kerja Karyawan Pada PT. Rubber Hock Lie Rantauprapat}

Kepuasan kerja dapat mempengaruhi loyalitas seseorang karyawan terhadap pekerjaan, bagaimana sikap senang atau tidak senang karyawan tersebut dalam pekerjaannya. Manfaat penelitian menurut Sunyoto (2012:140) adalah menciptakan sikap loyalitas dan kerja sama yang lebih menguntungkan. Setelah melakukan uji t, pelatihan berpengaruh secara positif tetapi tidak signifikan terhadap kepuasan kerja karyawan. Ini berarti pemberian pelatihan kurang memperngaruhi kepuasan kerja karyawan PT. Rubber Hock Lie karena karyawan dipercaya untuk menerima pelatihan tidak semua dapat mengembangkan pengetahuannya tersebut khususnya dalam pekerjaannya pekerjaannya. Hal ini dapat dilihat dari tanggapan responden terhadap pernyataan "Setelah mengikuti pelatihan, saya dapat menyelesaikan pekerjaan dengan cepat tepat sesuai dengan ketentuan" dimana sebanyak 24 orang menyatakan kurang setuju. Ini berarti karyawan PT. Rubber Hock Lie membutuhkan harus memotivasi para karyawan agar dapat mengimplementasikan pengetahuan yang telah diperoleh dari pelatihan untuk kemajuan perusahaan.

\section{c. Pengaruh Lingkungan Kerja Terhadap Kepuasan Kerja Karyawan Pada PT. Rubber Hock Lie Rantauprapat}

Salah satu faktor fisik yang mempengaruhi kepuasan kerja adalah lingkungan kerja (Sutrisno, 2013:80). Setelah melakukan uji t, lingkungan kerja berpengaruh secara positif dan signifikan terhadap kepuasan kerja karyawan, dan merupakan variabel yang paling dominan berpengaruh. Hal ini sesuai dengan jawaban responden yang menyatakan 
bahwa adanya interaksi yang baik antarkaryawan, pencahayaan yang cukup, ruangan kerja yang jauh dari kebisingan dan keamanan yang baik yang menunjukkan perasaan puas. Sehingga dapat dikatakan bahwa kondisi lingkungan kerja baik fisik maupun nonfisik di PT. Rubber Hock Lie dapat menunjang pekerjaan dan perasaan puas dari karyawan. Maka hal ini perlu diperhatikan oleh perusahaan dan juga bagi karyawan untuk sama-sama menjaga keadaan lingkungan kerja yang sudah baik menjadi lebih baik.

\section{d. Pengaruh Kesempatan Promosi, Pelatihan, dan Lingkungan Kerja Terhadap}

Kepuasan Kerja Karyawan Pada PT. Rubber Hock Lie Rantauprapat Hasil analisa statistik menunjukkan bahwa kesempatan promosi, pelatihan, dan lingkungan kerja bersama-sama berpengaruh positif dan signifikan terhadap variabel terikat, yaitu kepuasan kerja karyawan. Ini menandakan bahwa keseluruhan variabel kesempatan promosi, pelatihan dan lingkungan kerja berpengaruh terhadap kepuasan kerja karyawan PT. Rubber Hock Lie Rantauprapat. Hal ini didukung oleh teori yang dikemukakan Sutrisno (2013:80) dalam bukunya bahwa faktor-faktor yang mempengaruhi kepuasan kerja ada tiga yaitu faktor sosial; meliputi interaksi sosial antar karyawan ataupun dengan atasan, faktor fisik; meliputi jenis pekerjaan jam kerja, lingkungan kerja, dan faktor finansial; meliputi jaminan kesejahteraan seperti tunjangan, fasilitas, pelatihan, dan promosi.

\section{E. Kesimpulan dan Saran}

\section{Kesimpulan}

Berdasarkan hasil analisis yang telah dilakukan, maka penulis dapat mengambil beberapa kesimpulan sebagai berikut :

1. Secara parsial, kesempatan promosisecara positif dan signifikan terhadap kepuasan kerja karyawan pada PT. Rubber Hock Lie Rantauprapat.

2. Secara parsial, pelatihan berpengaruh positif dan tidak signifikan terhadap kepuasan kerja karyawan pada PT. Rubber Hock Lie Rantauprapat.

3. Secara parsial, lingkungan kerja berpengaruh secara positif dan signifikan terhadap kepuasan kerja karyawan pada PT. Rubber Hock Lie Rantauprapat.

4. Secara simultan, kesempatan promosi, pelatihan, dan lingkungan kerja berpengaruh secara positif dan signifikan terhadap kepuasan kerja karyawan pada PT. Rubber Hock Lie Rantauprapat.

5. Kepuasan kerja karyawan pada PT. Rubber Hock Lie Rantauprapat mampu dipengaruhi oleh kesempatan promosi, pelatihan, dan lingkungan kerja sebesar $61,4 \%$, dan sisanya dipengaruhi oleh variabel-variabel lain yang tidak dibahas dalam penelitian ini.

\section{Saran}

Berdasarkan hasil penelitian dan evaluasi, maka saran yang dapat diberikan penulis adalah sebagai berikut :

1. Variabel pelatihan dalam penelitian ini merupakan variabel yang berpengaruh tidak signifikan terhadap kepuasan kerja karyawan pada PT. Rubber Hock Lie Rantauprapat, oleh karena itu perusahaan harus lebih meningkatkan pemberian pelatihan kepada karyawan, agar karyawan dapat lebih baik dalam menyelesaikan pekerjaannya. 
2. Kepada karyawan yang telah memperoleh pelatihan dari perusahaan, diharapkan dapat mengimplementasikan ilmu yang telah diperoleh untuk kemajuan perusahaan.

3. Disarankan kepada perusahaan untuk dapat memperhatikan pemberian kesempatan promosi sebagai penghargaan terhadap kinerja karyawan agar dapat menciptakan kepuasan pada karyawan. Dan juga memperhatikan kondisi lingkungan kerja baik fisik ataupun non-fisik.

\section{DAFTAR PUSTAKA}

Anbri, Alvi, 2010. "Pengaruh Gaya Kepemimpinan dan Lingkungan Kerja terhadap Kinerja Karyawanpada PT. Bank Central Asia, Tbk KCP PuloBrayan Medan", Jurnal Ekonomi dan Bisnis, Vol. 2 No. 2.

Bangun, Wilson. 2012. ManajemenSumberDayaManusia.Jakarta :Erlangga.

Fribali, Budi Arief, 2014. "Pengaruh Pelatihan, Promosi Jabatan, serta Pemberian Insentif terhadap Kinerja Karyawan pada PT. Bank SUMUT Kantor Cabang Utama Medan”, JurnalEkonomidanBisnis, Vol. 1 No. 3.

Ghozali, Imam. 2007. AplikasiAnalisis Multivariate dengan Program SPSS. Semarang :BadanPenerbitUniversitasDiponegoro.

Hasibuan, Malayu S.P. 2011. ManajemenSumberDayaManusia. Jakarta :Bumi Aksara.

Kuncoro, Mudrajad. 2009. Metode Riset untuk Bisnis \& Ekonomi (Edisi 3).Jakarta :Erlangga.

Mangkunegara, Anwar Prabu. 2011. Manajemen Sumber Daya Manusia Perusahaan. Bandung :RemajaRosdakarya.

Nitisemito, Alex S., 2006. Manajemen Personalia:Manajemen Sumber Daya Manusia.EdisiKetiga. Jakarta :Ghalia Indonesia.

Sedarmayanti, 2009.Sumber Daya Manusia dan Produktivitas Kerja.Bandung :MandarMaju.

Situmorang, Syafrizal Helmi dan Muslich Lutfi.2012. Analisis Data untuk Riset Manajemen dan Bisnis.Medan : USU Press.

Sugiyono, 2012.Metode Penelitian Bisnis. Bandung :Alfabeta.

Sunyoto, 2013.Teori, Kuisioner, dan Analisis Data Sumbe rDaya Manusia.Yogyakarta : CAPS.

Sutrisno, Edy, 2013.ManajemenSumberDayaManusia. Jakarta :Kencana. 
Tarigan, Epta Riana, 2011. “Analisis Pengaruh Kompensasi dan Promosi Jabatan Terhadap Kepuasan Kerja Pegawai PT. Asuransi Jiwasraya Regional Office (RO) Medan".Repository USU, Medan. 